DOI 10.32900/2312-8402-2019-122-18-30

УДК 639.3:615.32:615.38

\title{
AN IN VITRO ASSESSMENT OF THE ANTI-AEROMONAS PROPERTIES OF LEAF EXTRACT OBTAINED FROM FICUS LYRATA WARB. (MORACEAE)
}

\author{
Pękala-Safińska A., Doctor of Biological Sciences, D.V.M. \\ Department of Fish Diseases, National Veterinary Research Institute, Pulawy, Poland \\ Tkachenko H., Doctor of Biological Sciences \\ Osadowski Z., Doctor of Biological Sciences \\ Institute of Biology and Environmental Protection, Pomeranian University in Słupsk, \\ Poland \\ Buyun L., Doctor of Biological Sciences \\ M. M. Gryshko National Botanic Garden, National Academy of Science of Ukraine, \\ Honcharenko V., Ph.D. \\ Ivan Franko Lviv National University \\ Prokopiv A., Ph.D. \\ Botanic Garden of Ivan Franko Lviv National University
}

The aim of the present study was to assess the antibacterial efficacy of ethanolic extracts derived from $F$. lyrata and its cultivar F. lyrata 'Bambino' against three Aeromonas strains (Aeromonas sobria, Aeromonas hydrophila, Aeromonas salmonicida subsp. salmonicida). The leaves of plants were collected in M. M. Gryshko National Botanic Garden (NBG, Kyiv, Ukraine) and Botanic Garden of Ivan Franko Lviv National University (Lviv, Ukraine). Freshly collected leaves were weighed and homogenized in $96 \%$ ethanol (in proportion 1:10) at room temperature. Three Aeromonas strains: Aeromonas sobria (K825) and Aeromonas hydrophila (K886), as well as Aeromonas salmonicida subsp. salmonicida (St30), originated from freshwater fish species such as common carp (Cyprinus carpio L.) and rainbow trout (Oncorhynchus mykiss Walbaum), respectively, were isolated in Department of Fish Diseases, The National Veterinary Research Institute in Pulawy (Poland). Bacteria were collected from fish exhibiting clinical disorders. Our results demonstrated that three Aeromonas strains (Aeromonas sobria, Aeromonas hydrophila, Aeromonas salmonicida subsp. salmonicida) were resistant to ethanolic extract derived from $F$. lyrata. The inhibition zone diameters were $(9.50 \pm 0.33 \mathrm{~mm}),(9.38 \pm 0.38 \mathrm{~mm})$, and $(9.5 \pm 0.5 \mathrm{~mm})$ for Aeromonas sobria, Aeromonas hydrophila and Aeromonas salmonicida subsp. salmonicida (St30), respectively. F. lyrata 'Bambino' extract exhibited the intermediate activity against Aeromonas sobria (inhibition zone diameter was $12 \pm 0.73 \mathrm{~mm}$ ), while Aeromonas hydrophila and Aeromonas salmonicida subsp. salmonicida (St30) were resistant (inhibition zone diameters were $9.18 \pm 0.54 \mathrm{~mm}$ and $9.13 \pm 0.44 \mathrm{~mm}$ ). These results pave the way for the possible development of natural additives to replace synthetic ones. Therefore, further investigations for the isolation of active constituents and their pharmacological evaluation as well as in vitro and in vivo study are required.

Keywords: Ficus lyrata, Ficus lyrata 'Bambino', Aeromonas sobria, Aeromonas hydrophila, Aeromonas salmonicida subsp. salmonicida, antimicrobial activity, disc diffusion technique, ethanolic extracts.

The genus Aeromonas, currently with 32 recognized species [13], is constituted by facultative anaerobic, Gram-negative, rod-shaped and non-spore-forming bacteria of 
approximately 1-3 $\mu \mathrm{m}$ in length [14, 26, 27]. Moreover, they are oxidase-positive, capable of fermenting glucose and characterized by tolerating increasing concentrations of $\mathrm{NaCl}$ varying from 0.3 to $5 \%[14,26]$. Aeromonas are emerging pathogens capable of colonizing and infecting several hosts [1]. They are inhabitants of marine environments, so fish and other seafood are the most common sources for isolating these microorganisms. Therefore, they are widely known in aquaculture as potentially infectious organisms and can cause diseases such as septicemia and furunculosis [14, 46].

The role of Aeromonas spp. as a causative agent of fish diseases have been known for decades, longer than their comparable role in causing systemic illnesses in humans [15]. Nevertheless, there are contradicting suggestions on whether the microbe is a primary agent of diseases or an opportunistic one causing diseases to hosts that are immune-compromised and stressed [23].

The fish disease is one of the major threats to the sustainable development of aquaculture causing loss of millions of dollars annually [47]. Disease prevention is the key issue to maintain the sustainable development of the aquaculture sector, both environmentally and economically. Widespread use of antibiotics in aquaculture has led to the development of antibiotic-resistant bacteria and the accumulation of antibiotics in the environment, resulting in water and soil pollution [8]. In recent years the use of antibiotics to treat and control fish diseases has been banned in the EU [4]. Prophylactic methods based on stimulation of the fish immune system (i.e., vaccination, probiotics, and immunostimulation) have been successfully used for this purpose and have become an integrated part of the management of modern aquaculture processes [20].

Plant extracts have been reported to favor various activities like anti-stress, growth promotion, appetite stimulation, enhancement of tonicity and immunostimulation, maturation of culture species, aphrodisiac and anti-pathogen properties in fish and shrimp aquaculture due to active principles such as alkaloids, terpenoids, tannins, saponins, glycosides, flavonoids, phenolics, steroids or essential oils [7, 30]. Plants belonging to Ficus L. genus and their constituents are used widely to prevent and treat human and animal diseases. The possible role and mode of action of these natural products are discussed with regard to the prevention and treatment of cancer, cardiovascular diseases including atherosclerosis and thrombosis, as well as their bioactivity as antibacterial, antiviral, antioxidants and antidiabetic agents [3, 6, 11, 19, 32, 49].

In our previous studies, the therapeutic potential for the use of various plants of Ficus genus in the control of bacterial diseases was evaluated against fish pathogens in in vitro study with promising results [33-44]. Most ethanolic extracts obtained from $\mathrm{Fi}$ cus spp. in our previous studies proved effective against the bacterial strain of Gramnegative A. hydrophila tested, with 10-12 mm zones of inhibition were observed. A. hydrophila demonstrated the highest susceptibility to $F$. pumila. The highest antibacterial activity against $A$. hydrophila (200 $\mu \mathrm{L}$ of standardized inoculum) was displayed by $F$. benghalensis, $F$. benjamina, F. deltoidea, F. hispida, F. lyrata leaf extracts [39]. Among various species of Ficus genus exhibiting moderate activity against $A$. hydrophila $(400 \mu \mathrm{L}$ of standardized inoculum), the highest antibacterial activity was displayed by $F$. benghalensis, $F$. benjamina, $F$. deltoidea, F. hispida, F. lyrata leaf extracts [41].

We have reported already data on the antioxidant and antibacterial effects of extracts from various plant belonged to the Ficus genus [33-44]. Our current scientific project undertaken in the frame of cooperation programme between Institute of Biology and Environmental Protection (Pomeranian University in Slupsk, Poland), Department of Fish Diseases, National Veterinary Research Institute (Pulawy, Poland), M. M. Gryshko National Botanic Gardens of National Academy of Sciences of 
Ukraine (Kyiv, Ukraine), and Ivan Franko Lviv National University (Lviv, Ukraine) directed to assessment of medicinal properties of tropical plants.

Therefore, the aim of the present study was to evaluate the antibacterial efficacy of ethanolic extracts derived from $F$. lyrata and its cultivar $F$. lyrata 'Bambino' against three Aeromonas strains (Aeromonas sobria, Aeromonas hydrophila, Aeromonas salmonicida subsp. salmonicida).

Materials and methods. Collection of plant material and preparing plant extract. The leaves of $F$. Lyrata and its cultivar $F$. lyrata 'Bambino' were collected in M. M. Gryshko National Botanic Garden (NBG, Kyiv, Ukraine) and Botanic Garden of Ivan Franko National University in Lviv (Lviv, Ukraine). The whole collections of tropical and subtropical plants both at NBG and Botanical Garden of Ivan Franko National University in Lviv (including Ficus spp. plants) have the status of a National Heritage Collection of Ukraine. The species author abbreviations were followed by Brummitt and Powell (1992).

Ficus lyrata Warb., commonly known as the fiddle-leaf fig, is a monoecious evergreen tree up to $15 \mathrm{~m}$ tall, native to western Africa. It belongs to those species known as hemi-epiphytes, which start life as an epiphyte in the crown of another tree and then send roots down to the ground enveloping the trunk of the host tree (Fig. 1). It can also grow as a terrestrial tree or shrub, especially in cultivation. Its leaves are broadly pandurate, 20-40 $\mathrm{cm}$ long and 10-30 $\mathrm{cm}$ wide, coriaceous and glabrous, with shortly acuminate apex and cordate base. Figs are axillary, sessile or occasionally pedunculate, globose, $4-6.5 \mathrm{~cm}$ in diameter, wrinkled, puberulous, at maturity greenish, often with paler spots $[5,28]$.

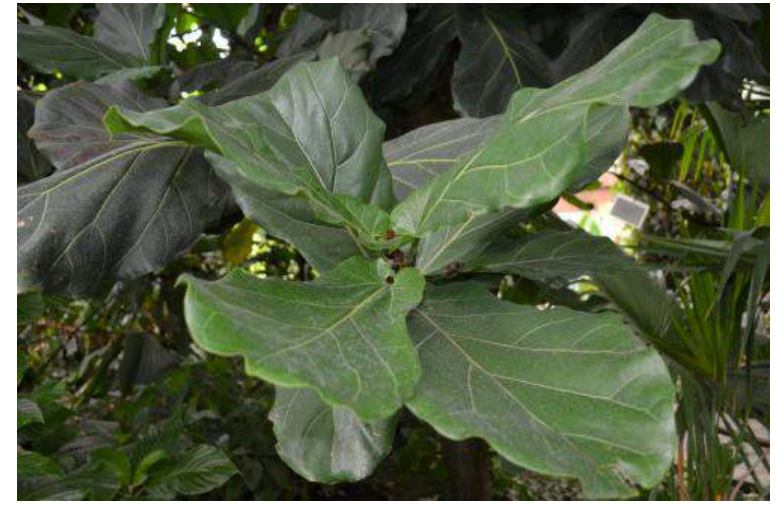

A

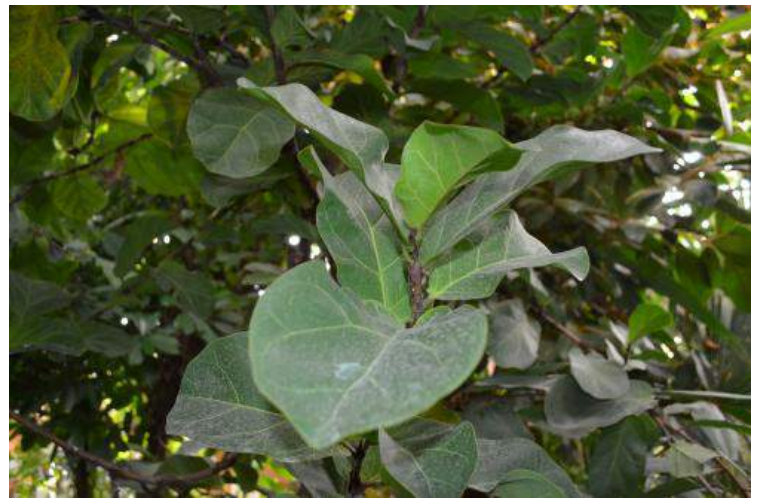

B

Fig. 1. Twigs of Ficus lyrata (A) and Ficus lyrata 'Bambino' (B), cultivated at M. M. Gryshko National Botanic Garden, National Academy of Science of Ukraine

The sampled leaves were brought into the laboratory for antimicrobial studies. Then, freshly collected leaves were weighed and homogenized in $96 \%$ ethanol (in proportion 1:10) at room temperature, and centrifuged at 3,000 g for 5 minutes. Supernatants were stored at $-20^{\circ} \mathrm{C}$ in bottles protected with the laminated paper until required.

Method of culturing pathological sample and identification method of the Aeromonas strains. Three Aeromonas strains: Aeromonas sobria (K825) and Aeromonas hydrophila (K886), as well as Aeromonas salmonicida subsp. salmonicida (St30), originated from freshwater fish species such as common carp (Cyprinys carpio L.) and rainbow trout (Oncorhynchus mykiss Walbaum), respectively, were isolated in Department of Fish Diseases, The National Veterinary Research Institute in Pulawy (Poland). Bacteria were collected from fish exhibiting clinical disorders. Each isolate was inoculated onto trypticase soy agar (TSA) (BioMérieux) and incubated at 
$27 \pm 2{ }^{\circ} \mathrm{C}$ for $24 \mathrm{~h}$. Pure colonies were used for biochemical identifications, according to the manufacturer's instructions, except the temperature of incubation, which was at $27 \pm 1{ }^{\circ} \mathrm{C}$. The following identification systems were used in the study: API 20E, API 20NE, API 50CH (BioMérieux). Presumptive Aeromonas isolates were further identified to the species level by restriction analysis of $16 \mathrm{~S}$ rDNA genes amplified by polymerase chain reactions (PCR) [17].

Bacterial growth inhibition test of plant extracts by the disk diffusion method. Antimicrobial susceptibility of the tested Aeromonas isolates was performed by the Kirby-Bauer disc diffusion method according to the recommendations of the Clinical and Laboratory Standards Institute (CLSI, 2014) [9, 10]. Each inoculum of bacteria in the density of $0.5 \mathrm{Mc}$ McFarland was cultured on Mueller-Hinton agar for $24 \mathrm{~h}$ at $28 \pm 2^{\circ} \mathrm{C}$. Seven drugs representing different antimicrobial classes as quinolones, tetracyclines, sulphonamides, and phenicols were used. After incubation, the inhibition zones were measured. Interpretation criteria have been adopted from that available for Aeromonas salmonicida [17].

Statistical analysis. Statistical analysis of the data obtained was performed by employing the mean \pm standard error of the mean (S.E.M.). All variables were randomized according to the phytochemical activity of strains tested. The following zone diameter criteria were used to assign susceptibility or resistance of bacteria to the phytochemicals tested: Susceptible $(\mathrm{S}) \geq 15 \mathrm{~mm}$, Intermediate $(\mathrm{I})=10-15 \mathrm{~mm}$, and Resistant $(\mathrm{R}) \leq 10 \mathrm{~mm}[25]$.

Results and discussion. The results of antimicrobial activity of an ethanolic extract derived from $F$. lyrata and F. lyrata 'Bambino' leaves against three Aeromonas strains are presented in Fig. 2.

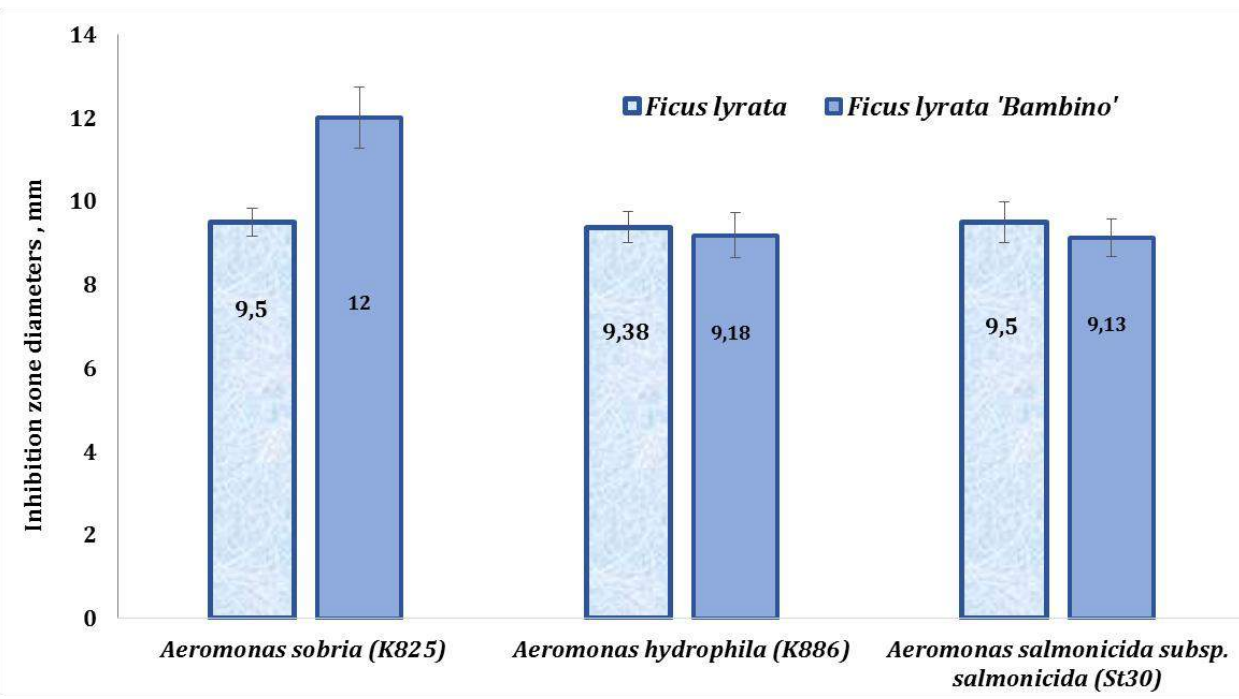

Fig. 2. The inhibition zone diameters of Aeromonas strains' growth (1000 $\mu \mathrm{L}$ inoculum) exhibited by the ethanolic extract derived from Ficus lyrata and $F$. lyrata 'Bambino' leaves $(\mathrm{M} \pm \mathrm{m}, \mathrm{n}=8)$.

Our results demonstrated that three Aeromonas strains (Aeromonas sobria, Aeromonas hydrophila, Aeromonas salmonicida subsp. salmonicida) were resistant to ethanolic extract derived from $F$. lyrata. The inhibition zone diameters were $(9.50 \pm 0.33 \mathrm{~mm}),(9.38 \pm 0.38 \mathrm{~mm})$, and $(9.5 \pm 0.5 \mathrm{~mm})$ for Aeromonas sobria, Aeromonas hydrophila and Aeromonas salmonicida subsp. salmonicida (St30), respectively. F. lyrata 'Bambino' extract exhibited the intermediate activity against Aeromonas sobria (inhibition zone diameter was $12 \pm 0.73 \mathrm{~mm}$ ), while Aeromonas hydrophila and Aer- 
omonas salmonicida subsp. salmonicida (St30) were resistant (inhibition zone diameters were $9.18 \pm 0.54 \mathrm{~mm}$ and $9.13 \pm 0.44 \mathrm{~mm}$ ) (Fig. 2).

The same results on $F$. lyrata were obtained in case of other bacterial strains in our previous study. Our results showed that the ethanolic extract of $F$. lyrata leaves exhibited moderate activity against the Gram-positive bacteria $(11.3 \mathrm{~mm}$ of inhibition zone diameter for Staphylococcus aureus), and the Gram-negative bacteria (10.3 $\mathrm{mm}$ for Escherichia coli). Klebsiella pneumonia, Pseudomonas aeruginosa, methicillinresistant Staphylococcus aureus, and Streptococcus pneumoniae appeared to be less sensitive to the extracts, the inhibition zone was $8.9 \mathrm{~mm}, 8.5 \mathrm{~mm}, 8.9 \mathrm{~mm}$, and $8.4 \mathrm{~mm}$, respectively [33].

F. lyrata showed potent antibacterial activity against Pseudomonas aeruginosa, Staphylococcus aureus, Shigella dysenteriae, Shigella boydii, Citrobacter freundii, Proteus vulgaris, Proteus mirabilis, Klebsiella in the study of Rizvi and co-workers (2009). The aqueous extract appeared more potent than alcoholic extract. Furthermore, the isolated compounds were more potent and showed an improved spectrum of activity as compared to the crude extract. The minimum inhibitory concentration (MIC) of aqueous extract of $F$. lyrata and the isolated compounds were found to be significantly low for all the tested bacterial strains. The study Rizvi and co-workers (2009) suggests that the extracts obtained from the leaves of $F$. lyrata possess excellent antibacterial activity [31].

Wira and co-workers (2018) have compared the potential utilization of $F$. lyrata fruit and leaf extract as antimicrobial agents. The predicted result of their research is a difference in the concentration of compound bioactive and antimicrobial activity between fruit and leaf extract. This research showed that extracts of $F$. lyrata fruit and leaf could use as antimicrobial resources. The phytochemical screening resulted in the water fruit leaf extract the presence of secondary metabolites like flavonoids, phenolic, and tannin. Antimicrobial activity was observed by the disc diffusion method against bacterial pathogens including Pseudomonas aeruginosa, Escherichia coli, and Bacillus subtilis. The result showed that the leaf extract has a higher of bioactive compounds than fruit extract, on the other side, antimicrobial activity is not a significant difference [48].

Other researchers also demonstrated the antimicrobial effects of plants belonging to the Ficus genus. For example, Valsaraj and co-workers (1997) evaluated activity of ethanolic extracts from $F$. benghalensis aerial roots and $F$. religiosa leaves, among a large number of plants, against four bacterial strains (Bacillus subtilis ATCC 6633, E. coli ATCC 11229, Pseudomonas aeruginosa ATCC 9027, and Staphylococcus aureus ATCC 6538) and two fungi (Aspergillus niger IMI 076837 and Candida albicans IMI 349010), using the agar dilution method for the former and agar-well diffusion method for the latter. Of these, only $F$. religiosa extracts were active against $P$. aeruginosa, showing weak inhibition at a concentration of $25 \mathrm{mg} / \mathrm{ml} \mathrm{[45].}$

Nimri and co-workers (1999) evaluated activity of 15 medicinal plant species ethanolic extracts against 14 bacterial strains, including Gram-positive bacteria (Bacillus cereus, Staphylococcus aureus ATCC 8095, S. epidermidis, Streptococcus pyogenes ATCC 12351, and Enterococcus faecalis) and Gram-negative bacteria (Shigella dysenteriae ATCC 49345, Yersinia enterocolitica ATCC 9610, E. coli ATCC 25922, clinical isolates E. coli B, 0111 and 2759, Klebsiella pneumoniae, Proteus vulgaris, and Pseudomonas aeruginosa). $P$. aeruginosa was inhibited by most of the plant extracts, being among the most susceptible microorganisms tested. However, all bacteria appeared resistant to the fruit extract of F. carica, the only Ficus species studied [24].

Farrukh and Ahmad (2003) investigated antimicrobial activity of ethanolic extracts of 22 Indian medicinal plant species against seven bacteria (Escherichia coli, 
Pseudomonas aeruginosa, Salmonella typhimurium, S. paratyphi, S. typhi, Shigella dysenteriae, and Staphylococcus aureus) and five filamentous fungi species (Alternaria alternata, Aspergillus niger, Fusarium chlamydosporum, Rhizoctonia bataticola, and Trichoderma viride). Of these, extracts from $F$. carica fruits and $F$. religiosa leaves were generally weakly effective (mostly 10 to $15 \mathrm{~mm}$ of inhibition zone diameter or no effect) with higher expression of antibacterial action. However, only $F$. carica extract was tested against $P$. aeruginosa, showing an inhibition zone of 11-15 mm. No inhibition of any organism tested caused the extracts from $F$. rumphii and $F$. benghalensis leaves [12].

Rajiv and Rajeshwari (2012) screened antimicrobial activity of $F$. religiosa bark, leaf, stem, and fruit aqueous extracts against a number of major pathogens (Aeromonas hydrophila, Enterobacter aerogenes, E. coli, Pseudomonas aeruginosa, Staphylococcus aureus, Streptococcus pyogenes, Aspergillus niger, and Candida albicans) and conducted their phytochemical analysis. All tested extracts appeared active against the pathogens at concentrations $25-100 \mathrm{mg} / \mathrm{ml}$, the widest inhibition zone $(15-16 \mathrm{~mm})$ resulting from the highest concentration. Fruit extract showed generally the weakest activity and only the leaf extract affected the whole set of tested organisms at maximal concentration. Antibacterial properties of the extracts were generally better pronounced than antifungal ones. All extracts at all concentrations tested affected $P$. aeruginosa, although the strongest inhibition showed the maximal concentration extracts from leaves and stems (inhibition zone diameter $14 \mathrm{~mm}$ ) and the slighter effect was produced by bark $(13 \mathrm{~mm})$ and fruit $(12 \mathrm{~mm})$ extracts. Qualitative phytochemical analysis showed the bark extract to have the richest chemical composition (sugar, alkaloids, phenols, and tannins present), being poorer in fruits (phenols and flavonoids), stem (sugar and tannins), and leaves (only tannins). Glycosides and terpenoids featured all extracts tested. Hence the most specific chemicals appeared to be alkaloids (found only in bark) and flavonoids (only in fruits), while tannins were common for the plant parts with the highest antimicrobial activity in general (i.e., bark, leaves, and stem). Although the authors present the results of phytochemical analysis, they do not make any inferences concerning possible contribution of particular chemical classes to the antimicrobial activity of plant extracts [29].

Nair and Chanda (2006) screened aqueous and ethanol extracts from 20 plant species, among which were four species of Ficus (F. benghalensis, F. racemosa, F. religiosa, and F. tisela), against seven Gram-negative (Pseudomonas aeruginosa ATCC27853, Pseudomonas testosteroni NCIM5098, Proteus mirabilis NCIM2241, Proteus vulgaris NCTC8313, Enterobacter aerogenes ATCC10240, Escherichia coli ATCC25922, and Citrobacter freundii ATCC10787) and five Gram-positive (Staphylococcus epidermidis ATCC12228, Bacillus cereus ATCC11778, Streptococcus fecalis ATCC29212, Streptococcus cremoris NCIM2179, and Streptococcus agalactiae NCIM2401) bacterial strains. Aqueous extracts generally showed less activity than ethanol extracts and Gram-positive bacteria were generally more affected than Gramnegative ones. The examined Ficus species, of which bark extracts were used, showed low inhibition activity in general. Only their methanolic extracts affected $P$. aeruginosa with small inhibition zone diameter, namely $3 \mathrm{~mm}$ for $F$. tisela, $2,5 \mathrm{~mm}$ for $F$. race$m o s a$, and $2 \mathrm{~mm}$ for $F$. benghalensis. Neither $F$. religiosa extract showed activity against $P$. aeruginosa [21].

Further studies (Nair and Chanda, 2007) tested aqueous and ethanol extracts from ten Indian plant species, including the same species of Ficus ( $F$. benghalensis, $F$. racemosa, $F$. religiosa, and $F$. tisela), against several medically important bacterial strains (Alcaligenes faecalis ATCC 8750, Bacillus cereus ATCC 11778, Pseudomonas 
aeruginosa ATCC 27853, Proteus mirabilis NCIM 2241, Salmonella typhimurium ATCC 23564, and Staphylococcus aureus ATCC 25923). The ethanol extracts were more potent than aqueous extracts of all the plants studied. Almost all Ficus bark extracts showed activity against each of the tested bacteria, although the strength of inhibition varied. $P$. aeruginosa was among the most resistant bacteria tested. Ficus species demonstrated low inhibition of $P$. aeruginosa, with inhibition zone diameter values of $3 \mathrm{~mm}$ ( $F$. benghalensis and $F$. tisela ethanolic extracts) and $2 \mathrm{~mm}(F$. racemosa ethanol extract). Aqueous extracts of all Ficus species and both extracts of $F$. religiosa appeared inactive against $P$. aeruginosa [22].

Atindehou and co-workers (2002) tested crude ethanol extracts from 115 plant species against Gram-negative bacteria (E. coli and Pseudomonas aeruginosa), Grampositive bacteria (Enterococcus faecalis and Staphylococcus aureus) and fungi (Candida albicans and Cladosporium cucumerinum). Among the examined plants, there were three Ficus species, namely $F$. exasperata, F. mucuso, and $F$. sur. The Gramnegative bacteria appeared unaffected by any plant extract tested, whereas the Grampositive bacteria and fungi were inhibited by at least several plant species. Among Ficus species tested, $F$. exasperata and $F$. mucuso had no significant effect on any microorganism, while $F$. sur appeared among the most active plant species against Grampositive bacteria [2].

Koné and co-workers (2004) screened crude ethanol extracts from 50 plant species of 31 families, among which were $F$. thonningii and $F$. vallis-choudae, for in vitro activity against Gram-negative (Escherichia coli and Pseudomonas aeruginosa) and Gram-positive (Staphyloccocus aureus, Enterococcus faecalis, Streptococcus pyogenes and Bacillus subtilis) bacteria. Only Gram-positive bacteria appeared inhibited by the tested extracts. Of two Ficus species examined, only F. thonningii leaf extracts showed activity against strains of E. faecalis and $S$. pyogenes. Furthermore, it was found one of the most active plant species against these two bacteria, showing inhibitory concentrations $\left(\mathrm{IC}_{100}\right)$ of $94 \mu \mathrm{g} / \mathrm{ml}$ on some resistant strains of E. faecalis and of $23-47 \mu \mathrm{g} / \mathrm{ml}$ on hospital strains of $S$. pyogenes. The inhibitory concentrations $\left(\mathrm{IC}_{100}\right)$ was defined as the lowest concentration of crude plant extract at which the visible growth of a strain was completely inhibited (no turbidity in wells) [16].

Kubmarawa and co-workers (2007) carried out an antimicrobial and phytochemical screening of 50 Nigerian plant species ethanolic extracts, among which were five species of Ficus (i.e., F. abutifolia (Miq.) Miq., F. platyphylla Del., F. polita Vahl, $F$. sycomorus L., and $F$. thonningii Blume). Microbial strains used in the study were Bacillus subtilis NCTC 8236, E. coli ATCC 9637, Pseudomonas aeruginosa ATCC 27853, Staphylococcus aureus ATCC 13709, and Candida albicans ATCC 10231. Ficus stem bark extracts demonstrated comparatively low antimicrobial activity, with the broadest activity spectrum being of $F$. thonningii extract (active against all microorganisms except $P$. aeruginosa and $S$. aureus). Extracts from $F$. polita and $F$. sycomorus showed no activity at all. $P$. aeruginosa was in general moderately susceptible compared to other bacteria tested, although no Ficus extract was active against it. Phytochemical analysis revealed the presence of only saponins and volatile oil in $F$. thonningii extract and saponins and flavonoids in $F$. polita extract, while richer chemical content was found in F. abutifolia (tannins, alkaloids, and volatile oil), F. platyphylla (saponins, flavonoids, alkaloids, and volatile oil), and F. sycomorus (glycosides, tannins, flavonoids, and volatile oil) extracts. However, the authors do not make any speculations regarding the contribution of particular chemical classes to the antimicrobial activity of plant extracts tested. Authors also suggest the presence of some compound 
classes (such as alkaloids) in plants to be affected by climatic and environmental factors [18].

Conclusions. The ethanolic extracts of Ficus lyrata and Ficus lyrata 'Bambino' were found to exhibit a mild antibacterial growth inhibitory effect against three Aeromonas strains. These results pave the way for the possible development of natural additives to replace synthetic ones. Therefore, further investigations for the isolation of active constituents and their pharmacological evaluation as well as in vitro and in vivo study are required.

\section{References}

1. Abu-Elala, N., Abdelsalam, M., Marouf, S., Setta, A. (2015). Comparative analysis of virulence genes, antibiotic resistance and gyrB-based phylogeny of motile Aeromonas species isolates from Nile tilapia and domestic fowl. Lett. Appl. Microbiol., 61(5), 429-436. DOI: 10.1111/lam.12484.

2. Atindehou, K. K., Koné, M., Terreaux, C., Traore, D., Hostettmann, K., Dosso, M. (2002). Evaluation of the antimicrobial potential of medicinal plants from the Ivory Coast. Phytotherapy Research, 16, 497-502. DOI: 10.1002/ptr.970.

3. Badgujar, S. B., Patel, V. V., Bandivdekar, A. H., Mahajan, R. T. (2014). Traditional uses, phytochemistry and pharmacology of Ficus carica: a review. Pharm. Biol., 52(11), 1487-1503. DOI: 10.3109/13880209.2014.892515.

4. Beltrán, J. M. G., Espinosa, C., Guardiola, F. A., Esteban, M. Á. 2018. In vitro effects of Origanum vulgare leaf extracts on gilthead seabream (Sparus aurata L.) leucocytes, cytotoxic, bactericidal and antioxidant activities. Fish Shellfish Immunol., 79, 1-10. DOI: 10.1016/j.fsi.2018.05.005.

5. Berg, C. C., Wiebes, J. T. (1992). African fig trees and fig wasps. Koninklijke Nederlandse Akademie van Wetenschappen, Verhandelingen Afdeling Natuurkunde, $2^{\text {de }}$ reeks, deel 89. North-Holland, Amsterdam, 298 p.

6. Bunawan, H., Amin, N. M., Bunawan, S. N., Baharum, S. N., Mohd Noor, N. (2014). Ficus deltoidea Jack: A Review on Its Phytochemical and Pharmacological Importance. Evid. Based Complement. Alternat. Med., 2014, 902734. DOI: $10.1155 / 2014 / 902734$.

7. Chakraborty, S. B., Hancz, C. (2011). Application of phytochemicals as immunostimulant, antipathogenic and antistress agents in finfish culture. Rev. Aquac., 3, 103-119. DOI: 10.1111/j.1753-5131.2011.01048.x.

8. Clarke, J. L., Waheed, M. T., Lössl, A. G., Martinussen, I., Daniell, H. (2013). How can plant genetic engineering contribute to cost-effective fish vaccine development for promoting sustainable aquaculture? Plant Mol. Biol., 83(1-2), 33-40. DOI: $10.1007 / \mathrm{s} 11103-013-0081-9$.

9. Clinical and Laboratory Standards Institute (CLSI) (2006) VET03-A Methods for antimicrobial disk susceptibility testing of bacteria isolated from aquatic animals, Approved Guideline. Vol. 26, No. 23, Wayne, PA, USA.

10. Clinical and Laboratory Standards Institute (CLSI) (2014) VET03-/VET04S2 Performance standards for antimicrobial susceptibility testing of bacteria isolated from aquatic animals, Second Informational Supplement. Vol. 34, No. 15, Wayne, PA, USA.

11. Dangarembizi, R., Erlwanger, K. H., Moyo, D., Chivandi, E. (2012). Phytochemistry, pharmacology and ethnomedicinal uses of Ficus thonningii (Blume Moraceae): a review. Afr. J. Tradit. Complement. Altern. Med., 10(2), 203-212. DOI: 10.4314/ajtcam.v10i2.4. 
12. Farrukh, A., Ahmad, I. (2003). Broad-spectrum antibacterial and antifungal properties of certain traditionally used Indian medicinal plants. World Journal of Microbiology and Biotechnology, 19, 653-657. DOI: 10.1023/A:1025128104056.

13. Figueras, M. J., Latif-Eugenín, F., Ballester, F., Pujol, I., Tena, D., Berg, K., Hossain, M. J., Beaz-Hidalgo, R., Liles, M. R. (2016). 'Aeromonas intestinalis' and 'Aeromonas enterica' isolated from human faeces, 'Aeromonas crassostreae' from oyster and 'Aeromonas aquatilis' isolated from lake water represent novel species. New Microbes New Infect., 15, 74-76. DOI: 10.1016/j.nmni.2016.11.019.

14. Gonçalves Pessoa, R. B., de Oliveira, W. F., Marques, D. S. C., Dos Santos Correia, M. T., de Carvalho, E. V. M. M., Coelho, L. C. B. B. (2019). The genus Aeromonas: A general approach. Microb. Pathog., 130, 81-94. DOI: 10.1016/j.micpath.2019.02.036.

15. Janda, J. M., Abbott, S. L. (2010). The genus Aeromonas: taxonomy, pathogenicity, and infection. Clin. Microbiol. Rev., 23(1), 35-73. DOI: 10.1128/CMR.0003909.

16. Koné, W.M., Atindehou, K.K., Terreaux, C., Hostettmann, K., Traoré, D., Dosso, M. (2004). Traditional medicine in North Côte-d'Ivoire: screening of 50 medicinal plants for antibacterial activity. Journal of Ethnopharmacology, 93, 43-49. DOI: 10.1016/j.jep.2004.03.006.

17. Kozińska, A. (2007). Dominant pathogenic species of mesophilic aeromonads isolated from diseased and healthy fish cultured in Poland. Journal of Fish Diseases, 30, 293-301. DOI: 10.1111/j.1365-2761.2007.00813.x.

18. Kubmarawa, D., Ajoku, G. A., Enwerem, N. M., Okorie, D. A. (2007). Preliminary phytochemical and antimicrobial acreening of 50 medicinal plants from Nigeria. African Journal of Biotechnology, 6(14), 1690-1696.

19. Lansky, E. P., Paavilainen, H. M. (2011). Figs: the genus Ficus. In: Hardman R. (ed.) Traditional herbal medicines for modern times, vol. 9. CRC Press, Boca Raton, p. 1-357.

20. Magnadottir, B. (2010). Immunological control of fish diseases. Mar. Biotechnol. (NY), 12(4), 361-379. DOI: 10.1007/s10126-010-9279-x.

21. Nair, R., Chanda, S. (2006). Activity of some medicinal plants against certain pathogenic bacterial strains. Indian Journal of Pharmacology, 38(2), 142-144. DOI: 10.4103/0253-7613.24625.

22. Nair, R., Chanda, S. V. (2007). Antibacterial activities of some medicinal plants of the western region of India. Turkish Journal of Biology, 31, 231-236. DOI: $10.1155 / 2018 / 2950758$.

23. Nielsen, M. E., Hoil, L., Chmidt, A. S., Qian, D., Shimada, T., Shen, J. Y., Larsen, J. L. (2001). Is Aeromonas hydrophila the dominant motile Aeromonas species that causes disease outbreaks in aquaculture production in the Zhejiang Province of China? Dis. Aquat. Organ., 46, 23-29. DOI: 10.3354/dao046023.

24. Nimri, L. F., Meqdam, M. M., Alkofahi, A. (1999). Antibacterial activity of Jordanian medicinal plants. Pharmaceutical Biology, 37(3), 196-201. DOI: $10.3109 / 13880209.2013 .853811$.

25. Okoth, D. A., Chenia, H. Y., Koorbanally, N. A. (2013). Antibacterial and antioxidant activities of flavonoids from Lannea alata (Engl.) Engl. (Anacardiaceae). Phytochem. Lett., 6, 476-481. DOI: 10.1016/j.phytol.2013.06.003.

26. Parker, J. L., Shaw, J. G. (2011). Aeromonas spp. clinical microbiology and disease. J. Infect., 62(2), 109-118. DOI: 10.1016/j.jinf.2010.12.003.

27. Percival, S. L., Williams, D. W. (2014). Aeromonas. Second ed., Elsevier. 
28. Protabase - Plant Resources of Tropical Africa. 2019-07-20. Website http://www.prota.org

29. Rajiv, P., Rajeshwari, S. (2012). Screening for phytochemicals and antimicrobial activity of aqueous extract of Ficus religiosa Linn. International Journal of Pharmacy and Pharmaceutical Sciences, 4, 207-209.

30. Reverter, M., Bontemps, N., Lecchini, D., Banaigs, B., Sasal, P. (2014). Use of plant extracts in fish aquaculture as an alternative to chemotherapy: Current status and future perspectives. Aquaculture, 433, 50-61. DOI: 10.1016/ j.aquaculture.2014.05.048.

31. Rizvi, W., Rizvi, M., Kumar, R., Kumar, A., Shukla, I., Parveen, M. (2009). Antibacterial Activity of Ficus lyrata - An In vitro Study. The Internet Journal of Pharmacology, 8(2).

32. Singh, D., Singh, B., Goel, R. K. (2011). Traditional uses, phytochemistry and pharmacology of Ficus religiosa: a review. J. Ethnopharmacol., 134(3), 565-583. DOI: $10.1016 /$ j.jep.2011.01.046.

33. Tkachenko, G., Buyun, L., Osadovskyy, Z., Truhan, M., Sosnowski, E., Prokopiv, A., Goncharenko, V. (2016). In vitro screening of antimicrobial activity of ethanolic extract obtained from Ficus lyrata Warb. (Moraceae) leaves. Agroecological Journal, 2, 155-160.

34. Tkachenko, H., Buyun, L., Kasiyan, O., Terech-Majewska, E., Honcharenko, V., Prokopiv, A., Osadowski, Z. (2018). Preliminary in vitro screening of antibacterial activity of leaf extract from Ficus natalensis subsp. natalensis Hochst. (Moraceae) against fish pathogens. Agrobiodiversity for Improving Nutrition, Health and Life Quality, (2), 170-183. DOI: 10.15414/agrobiodiversity.2018.2585-8246.170183.

35. Tkachenko, H., Buyun, L., Osadowski, Z., Honcharenko, V., Prokopiv, A. (2017). The antimicrobial efficacy of ethanolic extract obtained from Ficus benghalensis L. (Moraceae) leaves. Agrobiodiversity for improving nutrition, health, and life quality, 1, 438-445. DOI: 10.15414/agrobiodiversity.2017.2585-8246.438-445.

36. Tkachenko, H., Buyun, L., Osadowski, Z., Prokopiv, A., Honcharenko, V. (2017). Studies on antibacterial activity of Ficus binnendijkii Miq. (Moraceae) leaf extract. Visnyk Kyyivs 'koho natsional 'noho universytetu imeni Tarasa Shevchenka (Introduktsiya ta zberezhennya roslynnoho riznomanittya) [Bulletin of the Taras Shevchenko National University of Kyiv (Introduction and Conservation of Plant Diversity)], 1(35), $57-61$.

37. Tkachenko, H., Buyun, L., Osadowski, Z., Terech-Majewska, E., Honcharenko, V., Prokopiv, A. (2017). Comparative study of the antimicrobial efficacy of the ethanolic leaf extract of Ficus benghalensis L. (Moraceae) against bacterial fish pathogens. Stupskie Prace Biologiczne, 14, 209-228.

38. Tkachenko, H., Buyun, L., Terech-Majewska, E., Honcharenko, V., Prokopiv, A., Osadowski, Z. (2019). Preliminary in vitro screening of the antibacterial activity of leaf extracts from various Ficus species (Moraceae) against Yersinia ruckeri. Fish. Aquat. Life, 27, 15-26. DOI: 10.2478/aopf-2019-0002.

39. Tkachenko, H., Buyun, L., Terech-Majewska, E., Osadowski, Z. (2016). Antibacterial activity of ethanolic leaf extracts obtained from various Ficus species (Moraceae) against the fish pathogen, Citrobacter freundii. Baltic Coastal Zone - Journal of Ecology and Protection of the Coastline, 20, 117-136.

40. Tkachenko, H., Buyun, L., Terech-Majewska, E., Osadowski, Z. (2016). In vitro antimicrobial activity of ethanolic extracts obtained from Ficus spp. leaves against 
the fish pathogen Aeromonas hydrophila. Arch. Pol. Fish., 24, 219-230. DOI: 10.1515/aopf-2016-0019.

41. Tkachenko, H., Buyun, L., Terech-Majewska, E., Osadowski, Z. (2017). Antibacterial screening of ethanolic extracts obtained from leaves of various Ficus species (Moraceae) against Citrobacter freundii. In Trudy VNIRO, 167, 138-149.

42. Tkachenko, H., Buyun, L., Terech-Majewska, E., Osadowski, Z. (2017). Screening for antimicrobial activities of the ethanolic extract derived from Ficus hispida L. f. leaves (Moraceae) against fish pathogens. Научные труды Дальрыбвтуза (Scientific Journal of DALRYBVTUZ), 41, 56-64.

43. Tkachenko, H., Buyun, L., Terech-Majewska, E., Osadowski, Z. Sosnovskyi, Y., Honcharenko, V., Prokopiv, A. (2016). The antimicrobial activity of some ethanolic extracts obtained from Ficus spp. leaves against Aeromonas hydrophila. Trudy VNIRO, 162, 172-183.

44. Tkachenko, H., Buyun, L., Terech-Majewska, E., Osadowski, Z., Sosnovskyi, Y., Honcharenko, V., Prokopiv, A. (2016). In vitro antibacterial efficacy of various ethanolic extracts obtained from Ficus spp. leaves against the fish pathogen, Pseudomonas fluorescens. In Globalisation and regional environment protection. Technique, technology, ecology. Sci. eds T. Noch, W. Mikołajczewska, A. Wesołowska. Gdańsk, Gdańsk High School Publ., p. 265-286.

45. Valsaraj, R., Pushpangadan, P., Smitt, U.W., Adsersen, A., Nyman, U. (1997). Antimicrobial screening of selected medicinal plants from India. Journal of Ethnopharmacology, 58, 75-83. DOI: 10.1016/s0378-8741(97)00085-8.

46. Vega-Sánchez, V., Latif-Eugenín, F., Soriano-Vargas, E., Beaz-Hidalgo, R., Figueras, M. J., Aguilera-Arreola, M. G., Castro-Escarpulli, G. (2014). Reidentification of Aeromonas isolates from rainbow trout and incidence of class 1 integron and $\beta$-lactamase genes. Vet. Microbiol., 172(3-4), 528-533. DOI: 10.1016/j.vetmic.2014.06.012.

47. Vijayaraj, R., Sri Kumaran, N. (2017). Biosynthesis of silver nanoparticles from Hibiscus rosa sinensis: an approach towards antimicrobial activity on fish pathogen Aeromonas hydrophyla. International Journal of Pharmaceutical Sciences and Research, 8(8), 5241-5246. DOI: 10.13040/IJPSR.0975-8232.8(12).5241-46.

48. Wira, D. W., Mardawati, E., Setyowati, E. Y., Dahlan, A., Roostita, L., Balia (2018). The comparative study of the fruit and leaf extract of Ficus lyrata Warb on antibacterial activities. $2^{\text {nd }}$ Nommensen International Conference on Technology and Engineering, IOP Conf. Series: Materials Science and Engineering, 420, 012077.

49. Yadav, R. K., Nandy, B. C., Maity, S., Sarkar, S., Saha, S. (2015). Phytochemistry, pharmacology, toxicology, and clinical trial of Ficus racemosa. Pharmacogn. Rev., 9(17), 73-80. DOI: 10.4103/0973-7847.156356.

ИССЛЕДОВАНИЕ IN VITRО АНТИМИКРОБНЫХ СВОЙСТВ ЭКСТРАКТА ЛИСТЬEВ FICUS LYRATA WARB. (MORACEAE) В OTHOШЕНИИ ШTAMМOB AEROMONAS

Пенкала-Сафинская А., Национальный научно-исследовательский ветеринарный институт в Пулавах (Польша)

Ткаченко Г., Осадовский 3, Институт биологии и охраны окружающей среды Поморской Академии в Слупске (Слупск, Польша)

Буюн Л., Национальный ботанический сад имени Н. Н. Гришко НАН Украины, Киев, Украина

Гончаренко В., Львовский начиональный университет имени Ивана Франко, Львов, Украина 
Прокопив А., Ботанический сад Львовского наџионального университета имени Ивана Франко, Львов, Украина

Цель данного исследования состояла в определении антимикробной активности этанольного экстракта листьев F. lyrata и сорта F. lyrata 'Bambino' в отношении трех штаммов Aeromonas (Aeromonas sobria, Aeromonas hydrophila, Aeromonas salmonicida subsp. salmonicida). Образцы листьев были собраны в Национальном ботаническом саду имени Н.Н. Гришко (НБС, Киев, Украина) и Ботаническом саду Львовского национального университета имени Ивана Франко (Львов, Украина). Свежесобранные листья взвешивали и гомогенизировали в 96 \%-ном этаноле (в пропориии 1:10) при комнатной температуре. Три штамма Aeromonas: Aeromonas sobria (K825), Aeromonas hydrophila (K886), a также Aeromonas salmonicida subsp. salmonicida (St30), выделенные из видов пресноводных рыб, таких как карп обыкновенный (Cурrinus сагріо L.) и радужная форель (Oncorhynchus mykiss Walbaum), соответственно, были получены в Отделе заболеваний рыб Национального научно-исследовательского института ветеринарии в Пулавах (Польша). Материал для бактериологических исследований был выделен из рыб с видимыми клиническими проявлениями заболевания. Наши результаты свидетельствуют о том, что три штамма Aeromonas (Aeromonas sobria, Aeromonas hydrophila, Aeromonas salmonicida subsp. salmonicida) оказались резистентнылми к этанольнылм экстрактам листьев F. lyrata. Диаметр зоны ингибирова-

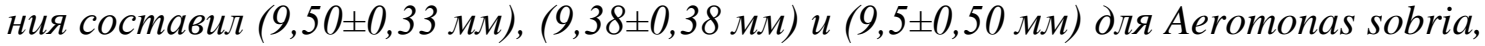
Aeromonas hydrophila u Aeromonas salmonicida subsp. salmonicida (St30), coomвemственно. Экстракт листьев F. lyrata 'Bambino' проявил промежуточную активность в отношении Aeromonas sobria (диаметр зоны ингибирования составил $12 \pm 0,73 \mathrm{мм})$, в то время как штаммы Aeromonas hydrophila u Aeromonas salmonicida subsp. salmonicida (St30) вылвили резистентность (диаметр зонь ин-

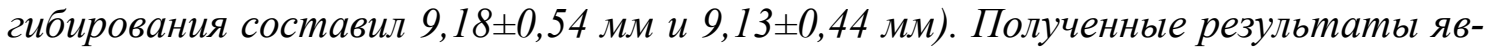
ляются предпосылкой для создания природных добавок, способных заменить синтетические. Следовательно, дальнейшие исследования, направленные на выделение активных веществ и их фармакологическое исследование как in vitro, так и in vivo, представляются нам крайне необходимыми.

Ключевые слова: Ficus lyrata, Ficus lyrata 'Bambino', Aeromonas sobria, Aeromonas hydrophila, Aeromonas salmonicida subsp. salmonicida, антимикробная активность, диско-диффузионный метод, этанольныле экстракты.

ДОСЛІДЖЕННЯ IN VITRO ВЛАСТИВОСТЕЙ ЕКСТРАКТУ ЛИСТКІВ FICUS LYRATA WARB. (MORACEAE) ПО ВIДНОШЕННЮ ДО ШТАМІВ AEROMONAS

Пенкала-Сафінська А., Наџіональний науково-дослідний ветеринарний інститут в Пулавах (Польщуа)

Ткаченко Г., Осадовський 3., Інститут біології та охорони навколишнього середовища Поморської Академї в Слупську (Слупськ, Польща)

Буюн Л., Національний ботанічний сад ім. М. М. Гришка НАН Украӥни

Гончаренко В., Львівський наџіональнылй університет ім. Івана Франка, Львів, Украӥна

Прокопів А., Ботанічний сад Львівського начіонального університету ім. Івана Франка, Львів, Україна

Мета даного дослідження полягала у визначенні антимікробної активності етанольного екстракту листків F. lyrata ma copmy F. lyrata 'Bambino' no відношенню до трьох штамів Aeromonas (Aeromonas sobria, Aeromonas 
hydrophila, Aeromonas salmonicida subsp. salmonicida). Зразки листків було зібрано в Національному ботанічному саду імені М. М. Гришка (НБС, Київ, Украӥна) та Ботанічному саду Львівського національного університету імені Івана Франка (Львів, Україна). Свіжсозібрані листки зважували та гомогенізували в 96\%-ному етанолі (у співвідношенні 1:10) при кімнатній температурі. Три штами Аeromonas: Aeromonas sobria (K825), Aeromonas hydrophila (K886), a також Aeromonas salmonicida subsp. salmonicida (St30), виділені з видів прісноводних риб, таких як короп звичайний (Cyprinus carpio L.) та райдужная форель (Oncorhynchus mykiss Walbaum), відповідно, були отримані у Відділі захворювань риб Національного науково-дослідного ветеринарного інституту в Пулавах (Польща). Матеріал для бактеріологічних досліджень було виділено з риб із вираженими клінічними проявами захворювання. Намі результати свідчать про те, щзо три штамu Aeromonas (Aeromonas sobria, Aeromonas hydrophila, Aeromonas salmonicida subsp. salmonicida) виявили резистентність до етанольних екстрактів листків

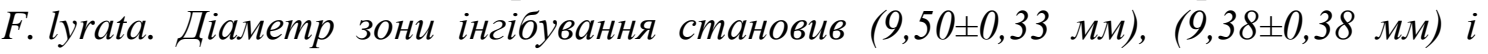
$(9,5 \pm 0,50$ мм) для Aeromonas sobria, Aeromonas hydrophila ma Aeromonas salmonicida subsp. salmonicida (St30), відповідно. Екстракт листків F. lyrata 'Bambino' виявив проміжну активність стосовно Aeromonas sobria (діаметр зони

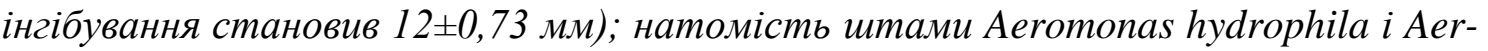
omonas salmonicida subsp. salmonicida (St30) виявили резистентність до дії екст-

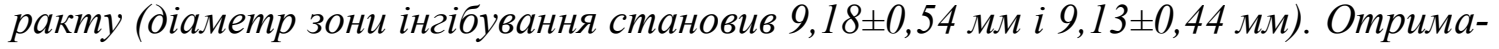
ні результати є передумовою для створення природних добавок, здатних замінити синтетичні. Відповідно, подільші дослідження, спрямовані на виділення активних сполук та їх фармакологічне дослідження як in vitro, так $i$ in vivo, $\epsilon$, на наш погляд, вкрай необхідними.

Ключові слова: Ficus lyrata, Ficus lyrata 'Bambino', Aeromonas sobria, Aeromonas hydrophila, Aeromonas salmonicida subsp. salmonicida, антимікробна активність, диско-дифузійний метод, етанольні екстракти.

DOI 10.32900/2312-8402-2019-122-30-42

УДК 639.3:615.32:615.38

\section{EVALUATION OF OXIDATIVE STRESS BIOMARKERS LEVELS IN THE EQUINE BLOOD AFTER IN VITRO TREATMENT WITH SANSEVIERIA CAULESCENS N.E.BR. EXTRACT}

Tkachenko H., Doctor of Biological Sciences

Osadowski Z., Doctor of Biological Sciences

Institute of Biology and Environmental Protection, Pomeranian University in Słupsk, Poland

Buyun L., Doctor of Biological Sciences

Maryniuk M., Post-graduatestudent

Kharchenko I., Ph.D.

M. M. Gryshko National Botanic Garden, National Academy of Science of Ukraine

The main goal of present study was to evaluate the level of the 2-thiobarbituric acid reactive substances (TBARS) as lipid peroxidation biomarker, aldehydic and ketonic derivatives of oxidatively modified proteins, and total antioxidant capacity in the equine erythrocytes' suspension induced by treatment of leaf extracts obtained from 